\title{
Protection against white spot syndrome virus (WSSV) infection in kuruma shrimp orally vaccinated with WSSV rVP26 and rVP28
}

\author{
Jun Satoh $^{1,2}$, Toyohiko Nishizawa ${ }^{2, *}$, Mamoru Yoshimizu ${ }^{2}$ \\ ${ }^{1}$ Aquatic Animal Health Division, National Research Institute of Aquaculture, Fisheries Research Agency, Saiki, \\ Oita 879-2602, Japan \\ ${ }^{2}$ Faculty of Fisheries Sciences, Hokkaido University, Hakodate 041-8611, Japan
}

\begin{abstract}
White spot syndrome virus (WSSV) is the causative agent of white spot disease (WSD), one of the most serious diseases affecting global shrimp farming. We compared WSSV infection induction in kuruma shrimp Marsupenaeus japonicus by oral, immersion, and intramuscular injection (IM) exposure methods and evaluated the oral vaccine prepared from the recombinant WSSV proteins rVP26 and rVP28. The $50 \%$ lethal doses $\left(\mathrm{LD}_{50}\right)$ of WSSV by oral, immersion, and IM challenges were $10^{-0.4}, 10^{-4.4}$, and $10^{-7.7} \mathrm{~g} \mathrm{shrimp}^{-1}$, respectively, indicating that WSSV infection efficiency by oral challenge was significantly less than the other 2 challenge routes. However, in shrimp farms it is believed that WSSV infection is easily and commonly established by the oral route as a result of cannibalization of WSSV-infected shrimp. Kuruma shrimp vaccinated orally with WSSV rVP26 or rVP28 were challenged with WSSV by oral, immersion, and IM routes to compare protection efficacy. The relative percent survival values were $100 \%$ for oral challenge, 70 to $71 \%$ for immersion, and 34 to $61 \%$ for IM. Thus, the protection against WSSV-infection that was induced in kuruma shrimp by oral vaccination with rVP26 or rVP28 seemed equivalent to that obtained through IM vaccination.
\end{abstract}

KEY WORDS: Oral vaccination · White spot syndrome virus · WSSV • Marsupenaeus japonicus • Kuruma shrimp · Quasi-immune response

\section{INTRODUCTION}

White spot disease (WSD, a synonym of penaeid acute viremia, PAV) is one of the most serious diseases of cultured decapod crustaceans throughout the world (Lightner 1996, Wang et al. 1998). White spot syndrome virus (WSSV, a synonym of penaeid rodshaped DNA virus, PRDV) (Inouye et al. 1996), the causative agent of WSD, is a member of the genus Whispovirus in the family Nimaviridae (Valk et al. 2004). WSSV is ovoid or ellipsoid to bacilliform in shape with regular symmetry (Wongteerasupaya et al. 1995). It is 120 to $150 \mathrm{~nm}$ in diameter and 270 to $290 \mathrm{~nm}$ in length, and has a thread- or flagellum-like appendage at one end (Wongteerasupaya et al. 1995). The virion consists of an inner, rod-shaped nucleocap- sid with a tight-fitting capsid layer and an outer, loose-fitting, lipid-containing trilaminar envelope (Durand et al. 1997). The viral nucleocapsid contains a DNA-protein core bounded by a distinctive capsid layer and a single molecule of circular doublestranded DNA with an approximate size of $300 \mathrm{kbp}$ (van Hulten et al. 2001, Yang et al. 2001). WSSV contains at least 6 major proteins: VP28 and VP19, which are associated with the envelope; VP664 and VP15, associated with the nucleocapsid; and VP24 and VP26, which are located in between the envelope and the nucleocapsid (van Hulten et al. 2000a,b, Chen et al. 2002, Leu et al. 2005, Tsai et al. 2006).

In the 1990s the kuruma shrimp Marsupenaeus japonicus culture industry in Japan was seriously damaged by outbreaks of WSD due to the importation of 
WSSV-contaminated kuruma shrimp seed stock originating from China (Nakano et al. 1994, Takahashi et al. 1994, 1998, Momoyama \& Muroga 2005). WSSV is pathogenic to kuruma shrimp beginning at the postlarval 10 stage (PL10) (Venegas et al. 1999). The major route of WSSV infection appeared to be through vertical transmission in kuruma shrimp hatcheries, because the occurrence of WSD in postlarvae notably decreased following selection of WSSV-free broodstock (Mushiake et al. 1999). However, horizontal transmission of WSSV, both by cannibalism and through waterborne exposure, is an infection route of concern in kuruma shrimp farms (Wu et al. 2001, Momoyama \& Muroga 2005). Stable seed production of specificpathogen-free (SPF) kuruma shrimp was accomplished using countermeasures for the prevention of WSSV, such as selection of WSSV-free broodstock by PCR, disinfection of eggs with iodine, and sterilization of rearing water (Mushiake et al. 1999, Satoh et al. 2001). At shrimp farms, however, it is still difficult to prevent WSSV infection due to horizontal transmission from other crustaceans present in the farm environment and cannibalism among reared shrimp (Maeda et al. 1998, Momoyama 2003).

Recently, Venegas et al. (2000) described a 'quasiimmune response' in kuruma shrimp wherein those that naturally survived WSD were protected against subsequent WSSV challenge. Protection against WSSV infection appeared $3 \mathrm{wk}$ after the primary infection and lasted 2 mo (Wu et al. 2002). Moreover, this protection toward WSSV showed a degree of specificity (Venegas et al. 2000). It is also possible to induce protection against WSSV by intramuscular (IM) injection with formalin-inactivated WSSV or with recombinant structural proteins of WSSV, rVP26 and rVP28 (Namikoshi et al. 2004). A similar degree of protection was also inducible in whiteleg shrimp Litopenaeus vannamei, giant tiger prawn Penaeus monodon, and crayfish Procambarus clarkii (Witteveldt et al. 2004a,b, 2006, Vaseeharan et al. 2006, Jha et al. 2006). As mentioned above, cannibalism may be one of the most important routes for the horizontal transmission of WSSV in kuruma shrimp farms; hence, the importance of oral vaccination with WSSV recombinant proteins. Recently, the effectiveness of oral vaccination with WSSV recombinant proteins in giant tiger prawns, whiteleg shrimp, and crayfish (Witteveldt et al. 2004a, 2006, Jha et al. 2006) has been reported. However, similar studies using kuruma shrimp, which require different environmental conditions for stocking and rearing (e.g. temperature) from other prawn and shrimp species, have not been reported. Thus, we investigated WSSV challenge routes for the development of an oral WSSV vaccine in kuruma shrimp, and diets containing rVP26 or rVP28 were fed to kuruma shrimp to evaluate their effectiveness as vaccines against experimental WSSV challenges by oral, immersion, and IM routes.

\section{MATERIALS AND METHODS}

Shrimp and WSSV inoculum. Kuruma shrimp (3.1 to $6.8 \mathrm{~g}$ ) were obtained from the Kamiura Station of Stock Enhancement Technology Development Center, National Research Institute of Aquaculture, Japan and a shrimp farm with no prior history of WSD located in Miyazaki Prefecture. Shrimp were confirmed to be WSSV-free by nested PCR before being used in the experiments. The shrimp were maintained in dechlorinated, electrolyzed, flow-through seawater (24 \pm $\left.1.8^{\circ} \mathrm{C}, 33.05 \pm 0.13 \mathrm{ppt}\right)$ using double-bottomed tanks with sand beds and fed a commercial crumble diet (Shrimp feed, Juveniles P-2; Maruha) at 3\% of body weight $\mathrm{d}^{-1}$.

The WSSV suspension was prepared following the method reported by Nonaka et al. (1998). Briefly, muscle tissue of moribund WSD-shrimp was homogenized with $4 \times$ the volume of phosphate-buffered saline (PBS) and then centrifuged at $3000 \times g$ for $10 \mathrm{~min}$ at $4^{\circ} \mathrm{C}$. The resulting supernatant was stored at $-85^{\circ} \mathrm{C}$ until used as a source of WSSV inoculum for the experiments.

Virulence of WSSV incoculum against shrimp. Shrimp were kept in $150 \mathrm{l}$ tanks at a density of 47 to 63 shrimp $\mathrm{m}^{-2}$ and were challenged with WSSV by oral, immersion, or IM routes.

In the IM challenge study, the stock WSSV solution was serially diluted with PBS from $10^{3}$ to $10^{7}$ at 10 -fold intervals. Shrimp with a mean body weight (MBW) of $6.8 \mathrm{~g}\left(\mathrm{n}=15\right.$ group $^{-1}, 6$ groups in total) were sedated by placement in $15^{\circ} \mathrm{C}$ seawater for $1 \mathrm{~min}$ and each shrimp was then intramuscularly injected with $100 \mu \mathrm{l}$ of each inoculum or PBS (negative control).

In the immersion challenge study, shrimp with MBW of $4.4 \mathrm{~g}$ ( $\mathrm{n}=20$ group $^{-1}, 4$ groups in total) were immersed for $1 \mathrm{~h}$ in $3 \mathrm{l}$ of WSSV solution diluted $10^{3}$-, $10^{4}$-, or $10^{5}$-fold with sterile seawater. Negative control shrimp were immersed in a $10^{3}$-fold diluted muscle homogenate prepared from healthy shrimp. After immersion the shrimp were placed in a net, rinsed with flowing seawater for $3 \mathrm{~min}$, and then returned to the rearing tanks.

In the oral challenge study, shrimp with MBW of $3.1 \mathrm{~g}\left(\mathrm{n}=15\right.$ group $^{-1}, 5$ groups in total) were fed WSD shrimp muscle at $0.25,0.4,0.65$, or $1.02 \mathrm{~g} \mathrm{shrimp}^{-1}$. The maximum amount given at one feeding was kept within $15 \%$ of the MBW $\left(\leq 0.5 \mathrm{~g} \mathrm{shrimp}^{-1}\right)$, thus, rations exceeding $0.5 \mathrm{~g}$ of WSD shrimp muscle were fed to the experimental shrimp in several portions over 2 to $3 \mathrm{~d}$. Control shrimp were given $1.02 \mathrm{~g}$ of healthy shrimp 
muscle in the same manner. The WSD shrimp muscle used for the oral challenge originated from the same source as that used to prepare the WSSV homogenate utilized in the immersion and IM challenges. Following each of the 3 exposures, the test shrimp were observed for $14 \mathrm{~d}$. The $50 \%$ lethal dose $\left(\mathrm{LD}_{50}\right)$ of the WSSV inoculum was calculated following the Behrens-Kärber method (Kärber 1931).

Preparation of shrimp diet containing rVP26 and rVP28. Recombinant WSSV proteins, rVP26 and rVP28, were prepared following the method of Namikoshi et al. (2004). Briefly, Escherichia coli cells, in which rVP26 or rVP28 had been induced by IPTG (isopropyl-1-1-thio- $\beta$-D-galactoside), were suspended in TE buffer (50 mM Tris- $\mathrm{HCl}$ and $2 \mathrm{mM} \mathrm{EDTA;}$ $\mathrm{pH} 8.0$ ) containing $0.1 \%$ Triton $\mathrm{X}-100$ and $0.1 \mathrm{mg} \mathrm{ml}^{-1}$ lysozyme and incubated at $30^{\circ} \mathrm{C}$ for $15 \mathrm{~min}$. After sonication to eliminate viscosity, the cell suspension was washed twice by centrifugation $(12000 \times g, 15 \mathrm{~min})$ and rVP26 and rVP28 were harvested from the insoluble fraction. Proteins for the negative control group were obtained from cultured E. coli cells with an empty vector by the same protocol, but without IPTGinducement. The resulting pellets containing rVP26, rVP28, or E. coli proteins were resuspended in PBS and analyzed by sodium dodecyl sulphate-polyacrylamide gel electrophoresis (SDS-PAGE) (Laemmli 1970). Analysis of density profiles from the digital images of the SDS-PAGE gels with ImageJ software (NIH) showed that the intensities of the prepared rVP26 and rVP28 were approximately 20 and 30\%, respectively (Fig. 1). For preparation of the oral vaccine, a commercial dry diet (Maruha) was soaked with suspensions containing either the rVP26, rVP28, or E. coli proteins using a volume equivalent to $5 \%$ of the feed weight $(\mathrm{w} / \mathrm{w})$ and the feed then coated with $0.5 \%$ volume $(\mathrm{w} / \mathrm{w})$ of an adhesive agent (ScheringPlough Animal Health).

Oral vaccination of shrimp with rVP26 and rVP28 for WSSV challenge tests. Kuruma test shrimp $(\mathrm{MBW}=3.7 \mathrm{~g})$ were divided into 4 groups $(\mathrm{n}=$ 100 group $^{-1}$ ) and fed a commercial diet that delivered $10 \mu \mathrm{g}$ of rVP26 or rVP28 $\mathrm{g}^{-1}$ of shrimp d $\mathrm{d}^{-1}, 25 \mu \mathrm{g}$ of $E$. coli proteins $\mathrm{g}^{-1}$ of shrimp $\mathrm{d}^{-1}$ (negative control 1), or PBS (negative control 2). These rations were provided for $15 \mathrm{~d}$. Ten days after the final feeding, shrimp fed rVP26 or rVP28 were divided into 7 groups each $(\mathrm{n}=$ 13 to 15 group $^{-1}$ ). Replicate groups of each viral protein vaccination were exposed to WSSV by the IM, immersion, or oral routes. The 2 remaining groups of shrimp that had been vaccinated with either rVP26 or rVP28 were mock challenged with WSSV to serve as negative controls. Forty-five shrimp that were fed the diets containing E. coli proteins or PBS were divided into 3 groups each ( $\mathrm{n}=13$ to 15 group $^{-1}$ ) and then challenged

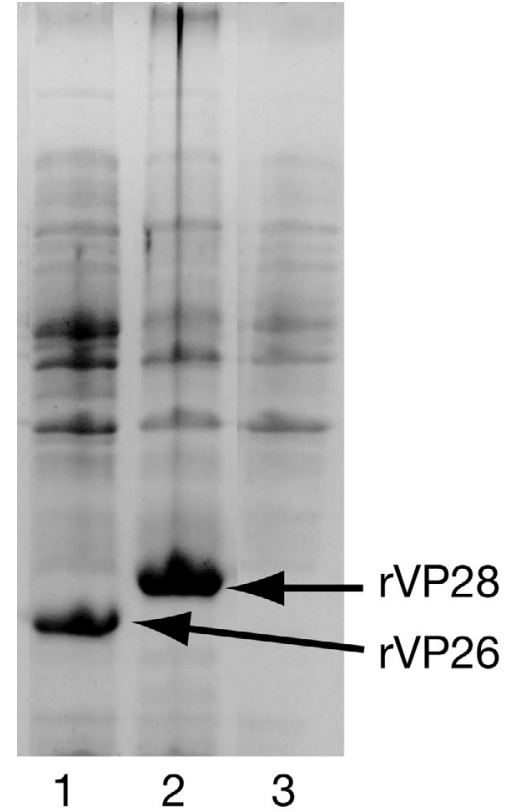

Fig. 1. SDS-PAGE analysis of expressed proteins, rVP26 and rVP28, of WSSV. Proteins in the $12 \%$ gel were stained with Coomassie brilliant blue. Lane 1: rVP26, lane 2: rVP28, lane 3: E. coli proteins

with WSSV by IM, immersion, or oral routes. The WSSV challenge doses were as follows: (1) IM challenge, $100 \mu \mathrm{l} \mathrm{shrimp}{ }^{-1}$ with $10^{4}$-fold dilution of the virus stock solution; $(2)$ immersion $(1 \mathrm{~h})$ challenge, $10^{4}$ fold dilution $\mathrm{ml}^{-1}$ of the virus stock solution; and (3) oral challenge, $0.6 \mathrm{~g}$ of WSD shrimp muscle shrimp ${ }^{-1}$ daily for $3 \mathrm{~d}$. During the oral challenge, complete consumption of the WSD shrimp muscle was visually confirmed. The WSSV doses used in each of the 3 challenge studies were adjusted to produce $70 \%$ cumulative mortality among non-vaccinated control shrimp based on the LD $_{50}$ data previously generated (Fig. 2).

In the experimental infection groups, dead shrimp were removed twice daily and stored at $-30^{\circ} \mathrm{C}$ for PCR analysis to confirm that WSSV infection was the cause of death. For the detection of WSSV by PCR, total DNA was extracted from shrimp following the method described by Nonaka et al. (1998), and 2 specific PCR primer sets were used: (1) P1 (5'-ATC ATG GCT GCT TCA CAG AC-3') and P2 (5'-GGC TGG AGA GGA CAA GAC AT-3') for the first-step PCR, and (2) P3 (5'TCT TCA TCA GAT GCT ACT GC-3') and P4 (5'-TAA CGC TAT CCA GTA TCA CG-3') for the nested PCR (Kimura et al. 1996).

Statistical analysis. The mortalities of the experimental versus control groups were analyzed using chisquared tests with a significance level of $1 \%$. The relative percentage survival (RPS) values were calculated according to the method of Amend (1981). 

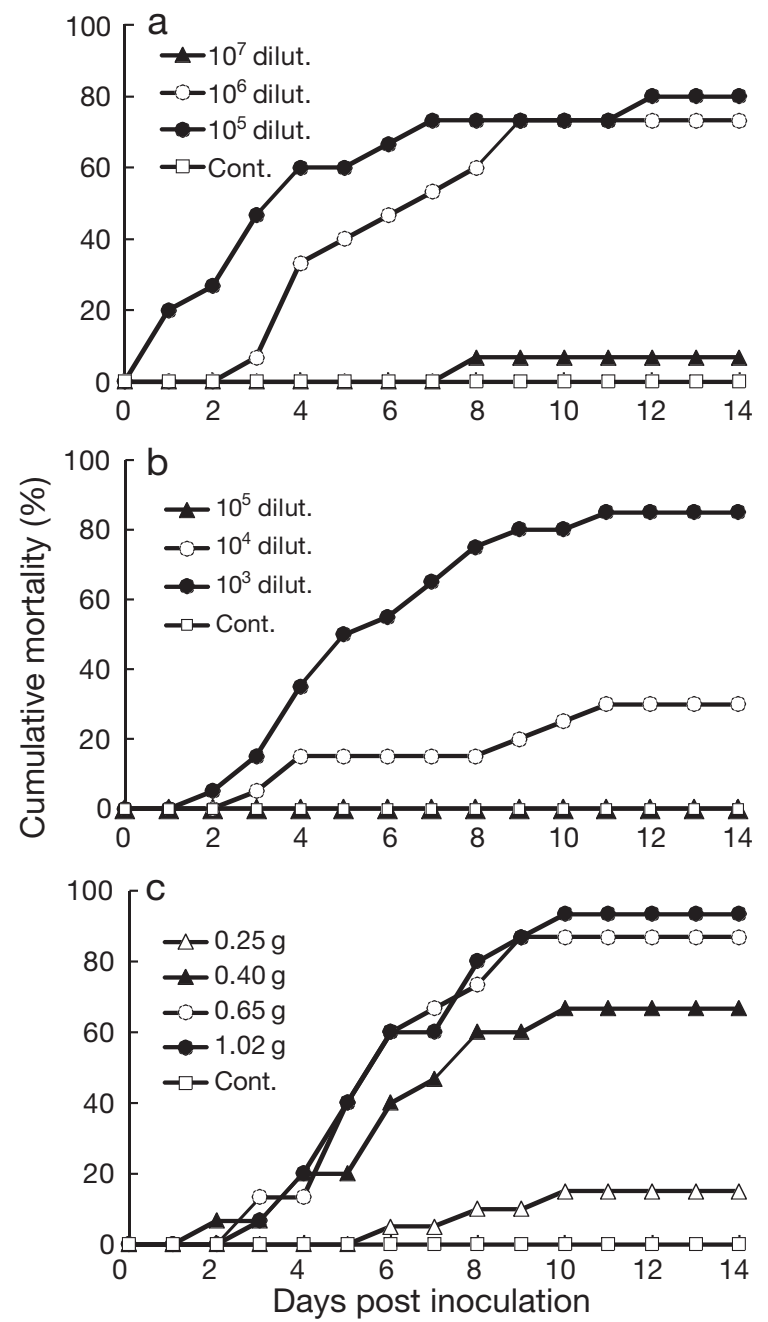

Fig. 2. Marsupenaeus japonicus. Cumulative mortality of kuruma shrimp after experimental WSSV challenge by 3 routes: (a) intramuscular challenge with $0.1 \mathrm{ml}$ of diluted WSSV solution, (b) immersion challenge with diluted WSSV solution, and (c) oral challenge with WSD shrimp muscle. Cont.: control group

\section{RESULTS}

\section{Virulence of WSSV inoculum against shrimp}

The virulence of WSD shrimp muscle and its homogenate was assessed in kuruma shrimp using 3 challenge methods: IM, immersion, and oral (Fig. 2). No mortality was observed among the negative control groups in each of the 3 challenge studies. In the IM challenge group that received the $10^{5.0}$-fold dilution of the WSSV solution, mortality was observed at $1 \mathrm{~d}$ post challenge (dpc) and reached $80 \%$ at 14 dpc. Mortality in the IM group challenged with the $10^{6.0}$-diluted WSSV solution started at $3 \mathrm{dpc}$ and the cumulative mortality was $73 \%$ at $14 \mathrm{dpc}$. In shrimp injected with $10^{7.0}$-diluted WSSV solution, the only death recorded was of 1 shrimp at $8 \mathrm{dpc}$ and the cumulative mortality was $6.7 \%$ (Fig. 2a). The calculated $\mathrm{LD}_{50}$ for the IM challenge route was $10^{-7.0} \mathrm{ml} \mathrm{shrimp} \mathrm{s}^{-1}$ (Table 1).

For the immersion exposure study, shrimp challenged with $10^{3.0}$-and $10^{4.0}$-diluted WSSV solutions started dying at 2 or $3 \mathrm{dpc}$ with cumulative mortalities of $85 \%$ and $30 \%$, respectively. No mortality was observed among the shrimp challenged with $10^{5.0}$ diluted WSSV solution (Fig. 2b). The $\mathrm{LD}_{50}$ of the WSSV solution administered by immersion was $10^{-3.7} \mathrm{ml} \mathrm{ml}^{-1}$ (Table 1).

In the oral exposure study, shrimp were challenged with $0.25,0.40,0.65$, and $1.02 \mathrm{~g}$ of WSD shrimp muscle and cumulative mortalities were 15, 67, 87, and $93 \%$, respectively (Fig. 2c). The $\mathrm{LD}_{50}$ of WSD shrimp muscle administered by the oral route was $0.37 \mathrm{~g} \mathrm{shrimp}^{-1}$ (Table 1).

\section{Protective ability of oral vaccination with rVP26 and rVP28 against WSSV}

After the oral administration of rVP26 and rVP28, shrimp were challenged with WSSV by oral, immersion, and IM exposure routes. The WSSV dose used in each of the 3 challenge studies was adjusted to induce $70 \%$ cumulative mortality among non-vaccinated control groups (administrated with PBS).

In the oral challenge study, shrimp vaccinated with E. coli proteins began dying 3 to $7 \mathrm{dpc}$ with a cumulative mortality of $31 \%$, significantly lower than the $67 \%$ cumulative mortality of the PBS (control) group $\left(\chi^{2}=3.59, \mathrm{p}<0.058\right)$. In contrast, no mortality was recorded in shrimp vaccinated with rVP26 or rVP28 (Fig. 3a). In shrimp challenged by immersion exposure to WSSV, mortality started 3 to $8 \mathrm{dpc}$ and the cumulative mortalities of shrimp vaccinated with rVP26, and rVP28 were $21 \%\left(\chi^{2}=11.008\right.$, p < 0.001) and $22 \%\left(\chi^{2}=11.008, \mathrm{p}<0.002\right)$, respectively, which were significantly lower than that of control shrimp with PBS (73\%) (Fig. 3b). No significant difference

Table 1. Virulence of WSSV in kuruma shrimp challenged by intramuscular, immersion, and oral routes

\begin{tabular}{|c|c|c|}
\hline \multirow{2}{*}{ Challenge route } & \multicolumn{2}{|c|}{$50 \%$ of lethal dose $\left(\mathrm{LD}_{50}\right)$} \\
\hline & Measured value ${ }^{a}$ & $\begin{array}{l}\text { Converted value } \\
\quad\left(g \text { shrimp }{ }^{-1}\right)\end{array}$ \\
\hline Intramuscular & $10^{-7.0} \mathrm{ml} \mathrm{shrimp}^{-1}$ & $10^{-7.7}$ \\
\hline Immersion & $10^{-3.7} \mathrm{ml} \mathrm{ml}^{-1}$ & $10^{-4.4}$ \\
\hline Oral & 0.37 g shrimp $^{-1}$ & $10^{-0.4}$ \\
\hline
\end{tabular}



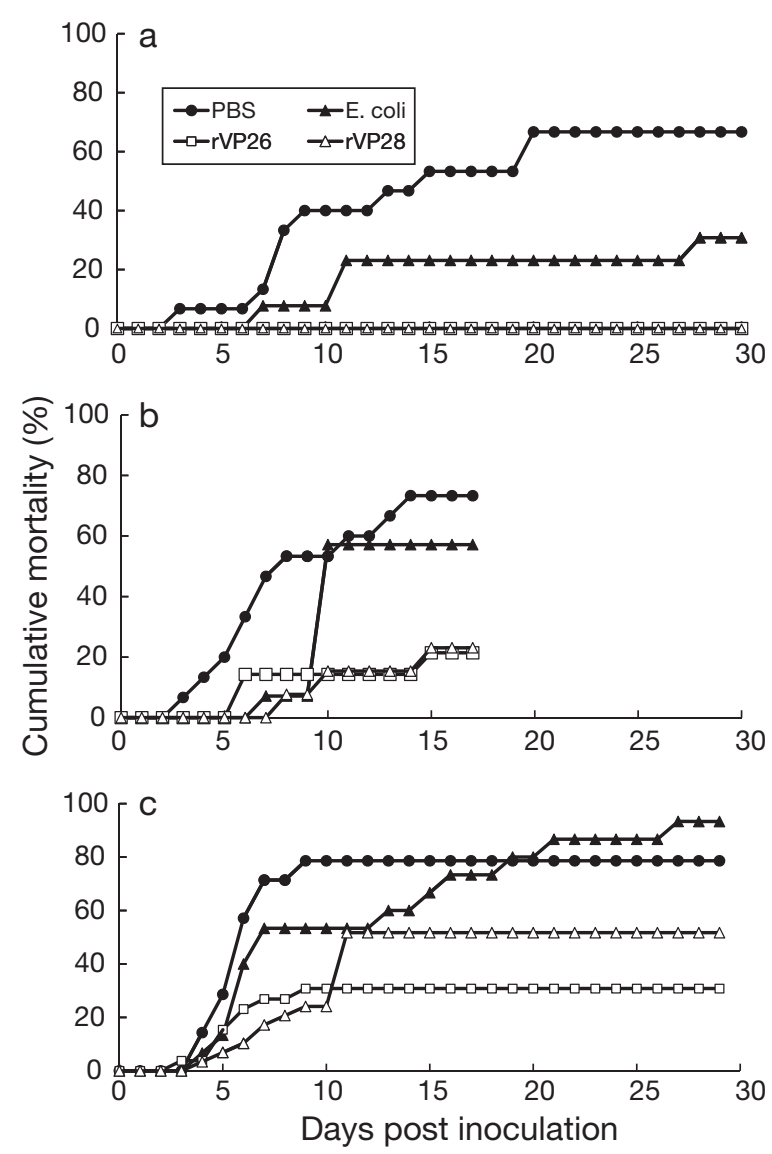

Fig. 3. Marsupenaeus japonicus. Cumulative mortality of kuruma shrimp vaccinated orally with WSSV rVP26 or rVP28 and challenged with WSSV by (a) oral challenge, (b) immersion challenge, and (c) intramuscular challenge

was observed in the cumulative mortalities between shrimp with E. coli proteins (57\%) and with PBS (Fig. 3b). In shrimp challenged by IM injection, mortality was observed beginning $3 \mathrm{dpc}$ and the cumulative mortalities of shrimp vaccinated with rVP26 and
rVP28 were $31 \%\left(\chi^{2}=8.34, \mathrm{p}<0.004\right)$ and $52 \%\left(\chi^{2}=\right.$ $2.85, \mathrm{p}<0.092)$, respectively, which were significantly lower than that with PBS $(79 \%)$. There was no significant difference in mortality between shrimp with $E$. coli proteins (93\%) and with PBS (Fig. 3c). No mortality was recorded in any of the 3 mock-challenged groups. The WSSV PCR results of the orally vaccinated shrimp for the 3 challenge routes are shown in Table 2. In the non-vaccinated control groups subjected to the 3 challenge routes, WSSV was detected in all dead shrimp by PCR and more than $66.7 \%$ of the surviving shrimp by nested PCR. Of the dead shrimp that had been vaccinated with rVP26 and rVP28, between 33 and $60 \%$ were positive for WSSV by PCR and between 73.3 to $100 \%$ were positive by nested PCR. However, all of the surviving shrimp vaccinated with rVPs were negative for WSSV by PCR and nested PCR with the exception of the oral and immersion challenge survivors in which $\leq 10 \%$ were found to be positive by nested PCR. These collective PCR results show that the prevalence of WSSV-infection in vaccinated shrimp was significantly lower than in non-vaccinated shrimp.

The calculated RPS values of orally vaccinated shrimp with rVP26 and rVP28 are shown in Table 3. Shrimp vaccinated with rVP26 showed $100 \%$ RPS after oral challenge, $71 \%$ after immersion challenge, and $61 \%$ after IM challenge; the corresponding values for those vaccinated with rVP28 were $100 \%, 70 \%$, and $34 \%$, respectively. Taken collectively, the RPS values of the orally vaccinated shrimp were all $>60 \%$ with the exception of the rVP28-vaccinated shrimp challenged with WSSV by the IM route (34\% RPS). The RPS values of shrimp vaccinated with $E$. coli proteins were $54 \%$ after oral challenge, $22 \%$ after immersion, and $0 \%$ after IM. These RPS values were significantly lower than those for shrimp vaccinated with rVP26 and rVP28 (Table 3).

Table 2. Marsupenaeus japonicus. PCR detection rates of WSSV in orally vaccinated shrimp after experimental challenge with WSSV by oral, immersion, and intramuscular (IM) routes. Nos. in parentheses: no. of positive/no. of examined. -: no cumulative mortality, nt: not tested

\begin{tabular}{|c|c|c|c|c|c|c|c|c|c|c|c|c|c|c|}
\hline \multirow[t]{2}{*}{$\begin{array}{l}\text { Anti- } \\
\text { gen }\end{array}$} & \multicolumn{4}{|c|}{$\begin{array}{c}- \text { Oral challenge }- \\
- \text { Dead }- \text { Survivors - }\end{array}$} & \multicolumn{4}{|c|}{$\begin{array}{l}- \text { Immersion challenge - }- \\
\text {-Dead }- \text { Survivors - }\end{array}$} & \multicolumn{4}{|c|}{$\begin{array}{c}- \text { IM challenge }- \text { Dead }-\quad \text { Survivors - }\end{array}$} & \multicolumn{2}{|c|}{$\begin{array}{l}\text { Mock challenge } \\
\text { - Survivors }\end{array}$} \\
\hline & PCR & $\begin{array}{l}\text { Nested } \\
\text { PCR }\end{array}$ & PCR & $\begin{array}{l}\text { Nested } \\
\text { PCR }\end{array}$ & PCR & $\begin{array}{l}\text { Nested } \\
\text { PCR }\end{array}$ & PCR & $\begin{array}{l}\text { Nested } \\
\text { PCR }\end{array}$ & PCR & $\begin{array}{l}\text { Nested } \\
\text { PCR }\end{array}$ & PCR & $\begin{array}{l}\text { Nested } \\
\text { PCR }\end{array}$ & PCR & $\begin{array}{l}\text { Nested } \\
\text { PCR }\end{array}$ \\
\hline rVP26 & - & - & $\begin{array}{c}0 \% \\
(0 / 30)\end{array}$ & $\begin{array}{l}6.7 \% \\
(2 / 30)\end{array}$ & $\begin{array}{c}50.0 \% \\
(3 / 6)\end{array}$ & $\begin{array}{c}83.3 \% \\
(5 / 6)\end{array}$ & $\begin{array}{c}0 \% \\
(0 / 22)\end{array}$ & $\begin{array}{l}9.1 \% \\
(2 / 22)\end{array}$ & $\begin{array}{c}50.0 \% \\
(4 / 8)\end{array}$ & $\begin{array}{c}100 \% \\
(8 / 8)\end{array}$ & $\begin{array}{c}0 \% \\
(0 / 18)\end{array}$ & $\begin{array}{l}38.9 \% \\
(7 / 18)\end{array}$ & $\begin{array}{c}0 \% \\
(0 / 12)\end{array}$ & $\begin{array}{c}0 \% \\
(0 / 12)\end{array}$ \\
\hline rVP28 & - & - & $\begin{array}{c}0 \% \\
(0 / 30)\end{array}$ & $\begin{array}{l}10 \% \\
(3 / 30)\end{array}$ & $\begin{array}{c}33.3 \% \\
(2 / 6)\end{array}$ & $\begin{array}{c}83.3 \% \\
(5 / 6)\end{array}$ & $\begin{array}{c}0 \% \\
(0 / 21)\end{array}$ & $\begin{array}{c}0 \% \\
(0 / 21)\end{array}$ & $\begin{array}{l}60.0 \% \\
(9 / 15)\end{array}$ & $\begin{array}{l}73.3 \% \\
(11 / 15)\end{array}$ & $\begin{array}{c}0 \% \\
(0 / 14)\end{array}$ & $\begin{array}{l}35.7 \% \\
(5 / 14)\end{array}$ & $\begin{array}{c}0 \% \\
(0 / 12)\end{array}$ & $\begin{array}{c}0 \% \\
(0 / 12)\end{array}$ \\
\hline E. coli & $\begin{array}{c}100 \% \\
(4 / 4)\end{array}$ & $\begin{array}{c}100 \% \\
(4 / 4)\end{array}$ & $\begin{array}{c}0 \% \\
(0 / 9)\end{array}$ & $\begin{array}{l}0 \% \\
(0 / 9)\end{array}$ & $\begin{array}{c}12.5 \% \\
(1 / 8)\end{array}$ & $\begin{array}{c}50.0 \% \\
(4 / 8)\end{array}$ & $\begin{array}{c}0 \% \\
(0 / 6)\end{array}$ & $\begin{array}{l}0 \% \\
(0 / 6)\end{array}$ & $\begin{array}{c}100 \% \\
(13 / 13)\end{array}$ & $\begin{array}{c}100 \% \\
(13 / 13)\end{array}$ & $\begin{array}{l}0 \% \\
(0 / 1)\end{array}$ & $\begin{array}{l}0 \% \\
(0 / 1)\end{array}$ & nt & nt \\
\hline PBS & $\begin{array}{c}100 \% \\
(10 / 10)\end{array}$ & $\begin{array}{c}100 \% \\
(10 / 10)\end{array}$ & $\begin{array}{c}40.0 \% \\
(2 / 5)\end{array}$ & $\begin{array}{c}100 \% \\
(5 / 5)\end{array}$ & $\begin{array}{c}100 \% \\
(11 / 11)\end{array}$ & $\begin{array}{c}100 \% \\
(11 / 11)\end{array}$ & $\begin{array}{c}25.0 \% \\
(1 / 4)\end{array}$ & $\begin{array}{c}75.0 \% \\
(3 / 4)\end{array}$ & $\begin{array}{c}100 \% \\
(11 / 11)\end{array}$ & $\begin{array}{c}100 \% \\
(11 / 11)\end{array}$ & $\begin{array}{c}0 \% \\
(0 / 3)\end{array}$ & $\begin{array}{c}66.7 \% \\
(2 / 3)\end{array}$ & $\mathrm{nt}$ & nt \\
\hline
\end{tabular}


Table 3. Marsupenaeus japonicus. Protection against WSSV challenge by oral, immersion, and intramuscular (IM) routes in kuruma shrimp vaccinated orally with rVP26 and rVP28. RPS: relative percent survival. * Significantly different $(1 \%$ level) from the non-vaccinated groups by $\chi^{2}$ test. -: no values, nt: not tested

\begin{tabular}{|c|c|c|c|c|c|c|c|c|c|c|c|}
\hline \multirow{2}{*}{ Antigen } & \multicolumn{3}{|c|}{ Oral challenge } & \multicolumn{3}{|c|}{ Immersion challenge } & \multicolumn{3}{|c|}{ IM challenge } & \multicolumn{2}{|c|}{ Mock challenge } \\
\hline & $\mathrm{n}$ & $\begin{array}{c}\text { Mortality } \\
(\%)\end{array}$ & $\begin{array}{l}\text { RPS } \\
(\%)\end{array}$ & $\mathrm{n}$ & $\begin{array}{l}\text { Mortality } \\
(\%)\end{array}$ & $\begin{array}{l}\text { RPS } \\
(\%)\end{array}$ & $\mathrm{n}$ & $\begin{array}{c}\text { Mortality } \\
(\%)\end{array}$ & $\begin{array}{l}\text { RPS } \\
(\%)\end{array}$ & $\mathrm{n}$ & $\begin{array}{l}\text { Mortality } \\
(\%)\end{array}$ \\
\hline rVP26 & 30 & $0^{*}$ & 100 & 28 & $21^{*}$ & 71 & 26 & $31^{*}$ & 61 & 12 & 0 \\
\hline rVP28 & 30 & $0^{*}$ & 100 & 27 & $22^{*}$ & 70 & 29 & 52 & 34 & 12 & 0 \\
\hline E. coli & 13 & 31 & 54 & 14 & 57 & 22 & 14 & 93 & 0 & nt & nt \\
\hline PBS & 15 & 67 & - & 15 & 73 & - & 14 & 79 & - & nt & nt \\
\hline
\end{tabular}

\section{DISCUSSION}

As a preliminary step towards the development of an oral vaccine against WSD in kuruma shrimp, the virulence of WSSV was compared using 3 different challenge routes. Measured $\mathrm{LD}_{50}$ values for WSSV by IM injection, immersion, and oral challenge routes were $10^{-7.0} \mathrm{ml} \mathrm{shrimp}^{-1}, 10^{-3.7} \mathrm{ml} \mathrm{ml}^{-1}$, and $0.37 \mathrm{~g} \mathrm{shrimp}^{-1}$, respectively. Since the WSSV stock solution for the virulence tests was prepared from the same lot of WSD muscle as that used to challenge the vaccinated shrimp, the measured $\mathrm{LD}_{50}$ values were used to calculate the approximate weight of WSD shrimp muscle used per shrimp in each of the 3 exposure studies. The resulting values were $10^{-7.7} \mathrm{~g} \mathrm{shrimp}^{-1}$ for the IM challenge, $10^{-4.4} \mathrm{~g} \mathrm{shrimp}^{-1}$ for the immersion challenge, and $10^{-0.4} \mathrm{~g} \mathrm{shrimp}^{-1}$ for the oral challenge study (Table 1). These results show that the quantity of WSSV-infected tissue needed to obtain an $\mathrm{LD}_{50}$ by the oral route was $10^{4.0}$ - and $10^{7.3}$-fold greater than that needed to achieve an $\mathrm{LD}_{50}$ by the immersion and IM routes, respectively. Standardization of the WSSV challenge dose was performed by Escobedo-Bonilla et al. $(2005,2006)$, which demonstrated that 10 times the dose was needed in the oral challenge as compared to the IM challenge in order to obtain the same cumulative mortality. While it is generally considered that the quantity of WSSV-infected tissue needed to achieve an $\mathrm{LD}_{50}$ varies according to exposure method, shrimp species, and viral strain, we did confirm that infection efficiency of WSSV by the oral route was significantly lower than by the immersion and IM routes.

Wu et al. (2001) suggested that cannibalism is one of the most important modes of WSSV transmission, as shrimp mortality decreased significantly when cannibalism was prevented in a WSSV infection experiment. Thus, it appears that WSSV infection is easily established when shrimp cannibalize WSD shrimp even though the efficiency of virus transmission by the oral route is low. Actually, a high frequency of cannibalism was also observed during the present study, meaning that it probably influenced the cumulative mortality of the shrimp. Cannibalism was permitted and high stocking densities were utilized to better duplicate actual farm conditions in an effort to evaluate the efficacy of the WSSV oral vaccine.

Protection against WSSV infection in shrimp is inducible by IM and oral inoculation with inactivated WSSV, rVP26, and rVP28 (Namikoshi et al. 2004, Witteveldt et al. 2004a,b, 2006, Jha et al. 2006). However, the experimental WSSV infections reported in these studies were by either IM or immersion challenge with the exception of the study by Jha et al. (2006). As described above, cannibalism is one of the most important modes of WSSV transmission in shrimp farms. Therefore, the effects of rVP26 and rVP28 vaccines should be evaluated using oral WSSV challenge. In the present study, $10 \mathrm{~d}$ after the final oral vaccination with rVP26, rVP28, or E. coli proteins, kuruma shrimp were challenged with WSSV by oral, immersion, and IM routes. We believe that the WSSV doses used for the experimental challenges were reasonably high and effective for our purposes as cumulative mortalities among groups of non-vaccinated control shrimp ranged from 67 to $79 \%$ (Table 3 ). Under these challenge conditions, RPS values of the rVP26 and rVP28 orally vaccinated shrimp were $100 \%$ for the oral challenge route and more than $70 \%$ for immersion (Table 3). Moreover, PCR analysis demonstrated that there was a significantly higher number of PCR positive non-vaccinated shrimp versus orally vaccinated shrimp (Table 2). Thus, it was confirmed that oral vaccination of kuruma shrimp with either rVP26 or rVP28 conferred adequate protection against ingested WSSV-infected tissue and can be utilized to prevent horizontal transmission of this virus through cannibalism in shrimp farms. Notably, the RPS values after IM challenge were lower than those after oral and immersion challenges (Table 3). Namikoshi et al. (2004) showed that booster vaccination of shrimp by the IM route with rVP26, rVP28, and formalin-inactivated WSSV led to enhanced protection against WSSV. In the present study, orally vaccinated shrimp showed adequate protection against WSSV after oral challenge 
even though the WSSV dose needed to achieve an infection by oral challenge was significantly higher than those needed to achieve infection by immersion and IM challenges (Table 1). Moreover, RPS values after oral challenge were also higher than those after immersion and IM challenges. These results strongly support the importance of the oral route mediated by cannibalism in the infection of shrimp with WSSV as described by Wu et al. (2001) and Momoyama \& Muroga (2005). Furthermore, our findings suggest that the horizontal transmission of WSSV through cannibalism in shrimp farms can be prevented by oral vaccination with rVP26 or rVP28.

In the present study, E. coli proteins were used as one of negative control vaccines because the $E$. coli cells were used to generate rVP26 and rVP28, and bacterial proteins comprised part of each vaccine as shown in Fig. 1. A low level of protection against WSSV challenge was observed in the control shrimp that were orally vaccinated with $E$. coli proteins, with a $54 \%$ RPS following oral WSSV challenge and $22 \%$ by immersion challenge (Table 3). We believe this low level of WSSV protection suggests that the E. coli proteins might have an immunostimulatory effect on the shrimp as in previous studies (Itami et al. 1998, Chen et al. 1999, Sritunyalucksana et al. 1999).

Wu et al. (2002) reported that resistance to WSSV in shrimp that survived WSD appeared 3 wk after primary infection and persisted for about 2 mo. However, Namikoshi et al. (2004) found that the protection induced by IM injection with formalin-inactivated WSSV did not persist any longer than that induced by natural infection. The present data shows that adequate protection was induced by oral vaccination of kuruma shrimp with either rVP26 or rVP28. The onset and duration of the protection induced by oral vaccination will be an interesting topic for further research.

Acknowledgements. We thank K. Mori of the National Research Institute of Aquaculture (NRIA) for technical assistance with the expression of recombinant proteins. This study was supported in part by a grant from the Fisheries Research Agency, and by a Grant-in-Aid from the Ministry of Education, Culture, Sports, Science, and Technology.

\section{LITERATURE CITED}

Amend DF (1981) Potency testing of fish vaccines. In: Anderson DP, Hennessen W (eds) Fish biologics: serodiagnostics and vaccines. Karger, Geneva, p 447-454

> Chang CF, Su MS, Chen HY, Lo CF, Kou GH, Lio IC (1999) Effect of dietary $\beta$-1,3-glucan on resistance to white spot syndrome virus (WSSV) in postlarval and juvenile Penaeus monodon. Dis Aquat Org 36:163-168

Chen LL, Leu JH, Huang CJ, Chou CM and others (2002) Identification of a nucleocapsid protein (VP35) gene of shrimp white spot syndrome virus and characterization of the motif important for targeting VP35 to the nuclei of transfected insect cells. Virology 293:44-53

> Durand S, Lightner DV, Redman RM, Bonami JR (1997) Ultrastructure and morphogenesis of White Spot Syndrome Baculovirus (WSSV). Dis Aquat Org 29:205-211

> Escobedo-Bonilla CM, Wille M, Alday-Sanz V, Sorgeloos P, Pensaert MB, Nauwynck HJ (2005) In vivo titration of white spot syndrome virus (WSSV) in specific pathogenfree Litopenaeus vannamei by intramuscular and oral routes. Dis Aquat Org 66:163-170

Escobedo-Bonilla CM, Audoorn L, Wille M, Alday-Sanz V, Sorgeloos P, Pensaert MB, Nauwynck HJ (2006) Standardized white spot syndrome virus (WSSV) inoculation procedures for intramuscular or oral routes. Dis Aquat Org 68: 181-188

Inouye $\mathrm{K}$, Yamano $\mathrm{K}$, Ikeda $\mathrm{N}$, Kimura $\mathrm{T}$, Nakano $\mathrm{H}$, Momoyama K, Kobayashi J (1996) The penaeid rodshaped DNA virus (PRDV), which causes penaeid acute viremia (PAV). Fish Pathol 31:39-45

Itami T, Asano M, Tokushige K, Kubono K and others (1998) Enhancement of disease resistance of kuruma shrimp, Penaeus japonicus, after oral administration of peptidoglycan derived from Bifidobacterium thermophilum. Aquaculture 164:277-288

Jha RK, Xu ZR, Shen J, Bai SJ, Sun JY, Li WF (2006) The efficacy of recombinant vaccines against white spot syndrome virus in Procambarus clarkii. Immunol Lett 105: $68-76$

Kärber G (1931) Beitrag zur kollektiven Behandlung pharmakologischer Reihenversuche. Arch Exp Pathol Pharmakol 162:480-483

Kimura T, Yamano K, Nakano H, Momoyama K, Hiraoka M, Inouye K (1996) Detection of penaeid rod-shaped DNA virus (PRDV) by PCR. Fish Pathol 31:93-98

> Laemmli UK (1970) Cleavage of structural proteins during the assembly of the head of bacteriophage T4. Nature 227: 680-685

> Leu JH, Tsai JM, Wang HC, Wang AHJ, Wang CH, Kou GH, Lo CF (2005) The unique stacked rings in the nucleocapsid of the white spot syndrome virus virion are formed by the major structural protein VP664, the largest viral structural protein ever found. J Virol 79:140-149

Lightner DV (1996) A handbook of pathology and diagnostic procedures for diseases of cultured penaeid shrimp. World Aquaculture Society, Baton Rouge, LA

> Lightner DV, Hasson KW, White BL, Redman M (1998) Experimental infection of western hemisphere penaeid shrimp with Asian white spot syndrome virus and Asian yellow head virus. J Aquat Anim Health 10:271-281

Maeda M, Itami T, Furumoto A, Hennig O and others (1998) Detection of penaeid rod-shaped DNA virus (PRDV) in wild-caught shrimp and other crustaceans. Fish Pathol 33: 373-380

Momoyama K (2003) Detection of white spot syndrome virus (WSSV) from small penaeid shrimp species caught in the Western Seto Inland Sea. Fish Pathol 38:81-85

Momoyama K, Muroga K (2005) Diseases of cultured kuruma shrimp in Japan: a review. Fish Pathol 40:1-14

Mushiake K, Shimizu K, Satoh J, Mori K, Arimoto M, Ohsumi S, Imaizumi K (1999) Control of penaeid acute viremia (PAV) in Penaeus japonicus: selection of eggs based on the PCR detection of the causative virus (PRDV) from Receptaculum seminis of spawned broodstock. Fish Pathol 34: 203-207

Nakano H, Koube H, Umezawa S, Mmoyama K, Hiraoka M, Inouye K, Oseko N (1994) Mass mortalities of cultured kuruma 
shrimp Penaeus japonicus in Japan in 1993: epizootiological survey and infection trials. Fish Pathol 29: 135-139

Namikoshi A, Wu JL, Yamashita T, Nishizawa T, Nishioka T, Arimoto M, Muroga K (2004) Vaccination trials with Penaeus japonicus to induce resistance to white spot syndrome virus. Aquaculture 229:25-35

Nonaka L, Venegas CA, Nishizawa T, Muroga K (1998) A method for nucleic acid extraction from kuruma prawn for PCR detection of PRDV (penaeid rod-shaped DNA virus). Fish Pathol 33:115-121

Satoh J, Mushiake K, Mori K, Arimoto M, Imaizumi K (2001) Control of penaeid acute viremia (PAV) in seed production of Penaeus japonicus. Bull Natl Res Inst Aquac (Jpn) Suppl 5:95-99

Sritunyalucksana K, Lee SY, Soderhall K (2002) A beta-1,3glucan binding protein from the black tiger shrimp, Penaeus monodon. Dev Comp Immunol 26:237-245

Takahashi Y, Itami T, Kondo M, Maeda M and others (1994) Electron microscopic evidence of bacilliform virus infection in kuruma shrimp (Penaeus japonicus). Fish Pathol 29:121-125

Takahashi Y, Itami T, Maeda M, Kondo M (1998) Bacteria and viral disease of kuruma shrimp (Penaeus japonicus) in Japan. Fish Pathol 33:357-364

Tsai JM, Wang HC, Leu JH, Wang AHJ and others (2006) Identification of the nucleocapsid, tegument, and envelope proteins of the shrimp white spot syndrome virus virion. J Virol 80:3021-3029

Valk JM, Bonami JR, Flegel TW, Kou GH and others (2004) Nimaviridae. In: Fauquet CM, Mayo MA, Maniloff J, Desselberger U, Ball LA (eds) VIIIth Rep Int Comm Taxon Viruses. Elsevier, Amsterdam, p 187-192

van Hulten MCW, Goldbach RW, Vlak JM (2000a) Three functionally diverged major structural proteins of white spot syndrome virus evolved by gene duplication. J Gen Virol 81:2525-2529

van Hulten MCW, Westenberg M, Goodall SD, Vlak JM (2000b) Identification of two major virion protein genes of white spot syndrome virus of shrimp. Virology 266: 227-236

van Hulten MCW, Witteveldt J, Snippe M, Vlak JM (2001) White spot syndrome virus envelope protein VP28 is involved in the systemic infection of shrimp. Virology 285:228-233

Editorial responsibility: Ken Hasson,

College Station, Texas, USA
Vaseeharan B, Anand TP, Murugan T, Chen JC (2006) Shrimp vaccination trials with the VP292 protein of white spot syndrome virus. Lett Appl Microbiol 43:137-142

Venegas CA, Nonaka L, Mushiake K, Shimizu K, Nishizawa T, Muroga K (1999) Pathogenicity of penaeid rod-shaped DNA virus (PRDV) to kuruma prawn in different developmental stages. Fish Pathol 34:19-23

Venegas CA, Nonaka L, Mushiake K, Nishizawa T, Muroga K (2000) Quasi-immune response of Penaeus japonicus to penaeid rod-shaped DNA virus (PRDV). Dis Aquat Org 42:83-89

Wang YC, Lo CF, Chang PS, Kou GH (1998) Experimental infection of white spot baculovirus in some cultured and wild decapods in Taiwan. Aquaculture 164:221-231

Witteveldt J, Cifuentes CC, Vlak JM, van Hulten MCW (2004a) Protection of Penaeus monodon against white spot syndrome virus by oral vaccination. J Virol 78: 2057-2061

Witteveldt J, Vlak JM, van Hulten MCW (2004b) Protection of Penaeus monodon against white spot syndrome virus using a WSSV subunit vaccine. Fish Shellfish Immunol 16: 571-579

- Witteveldt J, Vlak JM, van Hulten MCW (2006) Increased tolerance of Litopenaeus vannamei to white spot syndrome virus (WSSV) infection after oral application of the viral envelope protein VP28. Dis Aquat Org 70:167-170

> Wongteerasupaya C, Vickers JE, Sriurairatana S, Nash GL and others (1995) A non-occluded, systemic baculovirus that occurs in cells of ectodermal and mesodermal origin and causes high mortality in the black tiger prawn Penaeus monodon. Dis Aquat Org 21:69-77

> Wu JL, Namikoshi A, Nishizawa T, Mushiake K, Teruya K, Muroga K (2001) Effects of shrimp density on transmission of penaeid acute viremia in Penaeus japonicus by cannibalism and the waterborne route. Dis Aquat Org 47: 129-135

Wu JL, Nishioka T, Mori K, Nishizawa T, Muroga K (2002) A time-course study on the resistance of Penaeus japonicus induced by artificial infection with white spot syndrome virus. Fish Shellfish Immunol 13:391-403

- Yang F, He J, Lin X, Li Q, Pan D, Zhang X, Xu X (2001) Complete genome sequence of the shrimp white spot bacilliform virus. J Virol 75:11811-11820

Submitted: October 2, 2007; Accepted: August 14, 2008 Proofs received from author(s): October 1, 2008 